\title{
Policy transfer of the directly observed treatment of tuberculosis: speeches of health managers
}

\author{
Transferência de política do tratamento diretamente observado \\ da tuberculose: discursos de gestores da saúde \\ Transferencia de políticas del tratamiento directamente observado \\ de la tuberculosis: discursos de los gestores de salud
}

\section{Karinne Dantas de Oliveira Adário ${ }^{a}$ Rita de Cassia Cordeiro de Oliveirab Arieli Rodrigues Nóbrega Videres ${ }^{c}$ Amanda Haissa Barros Henriques ${ }^{b}$ Pedro Fredemir Palhad ${ }^{d}$}

How to cite this article: Adário KDO, Oliveira RCC, Videres ARN, Henriques AHB, Palha PF, Barrêto, AJR. P0licy transfer of the directly observed treatment of tuberculosis: speeches of health gestores da saúde. Rev Gaúcha Enferm. 2021;42:e20200427. doi: https://doi. org/10.1590/1983-1447.2021.20200427 a Secretaria Municipal de Saúde, Diretoria de Gestão de Trabalho e Educação na Saúde. João Pessoa, Paraíba, Brasil.

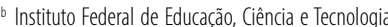
da Paraíba (IFPB), Campus Avançado João Pessoa Mangabeira. João Pessoa, Paraíba, Brasil.

Universidade Federal de Campina Grande (UFCG), Centro de Formação de Professores. Cajazeiras, Paraíba, Brasil.

d Universidade de São Paulo (USP), Escola de Enfermagem de Ribeirão Preto, Centro Colaborador da OPAS/OMS para o Desenvolvimento da Pesquisa em Enfermagem. Ribeirão Preto, São Paulo, Brasil.

e Universidade Federal da Paraíba (UFPB), Centro de Ciências da Saúde, Programa de Pós-graduação em Enfermagem. João Pessoa, Paraíba, Brasil.

\section{ABSTRACT}

Objective: To analyze the effects of meanings produced by the speechess of health managers about the Policy Transfer of Directly Observed Treatment of Tuberculosis.

Method: Qualitative study developed in 2017 with six managers working in health services located in municipalities in the state of Paraiba. The corpus, constituted by interviews, was analyzed by Discourse Analysis.

Results: The speeches expressed aspects favorable to the operationalization of the policy transfer process, such as investing in human, technological, physical and material resources; coordinating management in the organization of the network and raising the awareness of the professionals involved. Barriers were identified, such as the prevalence of cases in the Reference Unit; professional turnover; prejudice and social vulnerability.

Conclusions: The study showed that financial investments, government pacts and commitment of the actors involved in the production of care are necessary to carry out the policy transfer process in the municipalities investigated.

Keywords: Health management. Tuberculosis. Primary health care. Qualitative research. Health policy.

\section{RESUMO}

Objetivo: Analisar os efeitos de sentidos produzidos pelos discursos de gestores em saúde sobre a Transferência de Política do Tratamento Diretamente Observado da Tuberculose.

Métodos: Estudo qualitativo, desenvolvido em 2017, com seis gestores atuantes em serviços de saúde localizados em municípios do estado da Paraíba. 0 corpus, coletado por meio de entrevistas, foi analisado sob a perspectiva da Análise de Discurso.

Resultados: Os discursos expressaram aspectos favoráveis para operacionalizar o processo de transferência de política, como o investimento em recursos humanos, tecnológicos, físicos e materiais; articular a gestão na organização da rede e sensibilizar os profissionais envolvidos. Identificaram-se barreiras como a prevalência de casos na Unidade de Referência, rotatividade de profissionais, preconceito e vulnerabilidade social.

Conclusões: 0 estudo evidenciou que são necessários investimentos financeiros, pactuações governamentais e compromisso dos atores envolvidos na produção de cuidado para efetivar o processo de transferência de política nos municípios em estudo.

Palavras-chave: Gestão em saúde. Tuberculose. Atenção primária à saúde. Pesquisa qualitativa. Política de saúde.

\section{RESUMEN}

Objetivo: Analizar los efectos de los significados producidos por los discursos de los gestores de salud sobre la Política de Transferencia de Tratamiento Directamente Observado de la Tuberculosis.

Método: Estudio cualitativo, desarrollado en 2017, con seis gerentes trabajando en servicios de salud ubicada en municipios del estado de Paraíba. El corpus recopilado a través de entrevistas, fue analizado por Discourse Analysis.

Resultados: Los discursos expresaron aspectos favorables para la operacionalización del proceso de transferencia de políticas, como la inversión en recursos humanos, tecnológicos, físicos y materiales; la articulación de la gestión en la organización de la red y la sensibilización de los profesionales implicados. Se identificaron barreras como la prevalencia de casos en la Unidad de Referencia; rotación profesional; prejuicio y vulnerabilidad social.

Conclusiones: El estudio mostró que las inversiones financieras son necesarias, pactos de gobierno y compromiso de los actores involucrados en la producción de cuidados con el propósito de llevar a cabo el processo de transferencia de políticas en los municipios en estudio.

Palabras clave: Gestión em salud. Tuberculosis. Atención primaria de salud. Investigación cualitativa. Política de salud. 


\section{口INTRODUCTION}

The high tuberculosis (TB) mortality rate has been persistent, especially among the financially and socially disadvantaged population groups, and has been neglected as a public health policy, as demonstrated by the World Health Organization (WHO) (1).

In 2018,72,788 new cases of TB were recorded in Brazil, which corresponds to an incidence of 34.8 cases/100 thousand inhabitants. Despite the average annual decline of 1.0\% between 2009 and 2018, the incidence coefficient in 2017 and 2018 exceeded the coefficient observed in the 20142016 period, which may represent an increase in access to diagnostic devices. However, the incidence of the disease has been socially determined through individual, contextual and programmatic aspects, as well as due to the economic crises that may have contributed to increase this incidence in the Brazilian context ${ }^{(2)}$.

TB control policy, both globally and nationally, has been prioritized in recent decades, since the emergence of the Direct Observed Treatment Strategy (DOTs), in 1993; later with the introduction of the Stop TB strategy, and currently, with the End TB strategy ${ }^{(3)}$

One of the recommended strategic measures for TB control is the use of directly observed treatment (DOT) covering $90 \%$ of the population, as a key support action that contributes to monitoring the treatment of patients and increasing adherence to therapy, which implies the commitment of all professionals involved ${ }^{(3)}$.

The DOT has consistently improved the rate of cure and reduced TB dropout rate ${ }^{(1)}$ in Primary Health Care (PHC). However, the operationalization of this treatment and the geopolitical scenario have affected the decentralization of these actions in different territorial contexts and PHC (4) care models, which may interfere with TB control indicators.

The decentralization of technical actions for TB control has not been homogeneous, differing according to the different contexts and scenarios. Therefore, managers must formulate innovative and decisive strategies for the establishment of an efficient process of Policy Transfer of the Tuberculosis Control Program Policy aimed at the sustainability and coordination of actions between the different levels of care and management of the health system, based on the priorities listed in each context ${ }^{(5)}$.

The PT is a movement in which knowledge, ideas, institutions, policies and programs, in one time or space, are placed in the decision arena for the development of policies and programs in another time and context. Therefore, PT is the result of strategic decisions taken by individuals inside and outside the government and/ or between different levels of government in the same country ${ }^{(6)}$. It presupposes a participatory, continuous process and effective involvement between management and workers in the process of construction, operation and evaluation of the transfer of certain public policies, in the most varied scenarios, with an emphasis on innovative actions aimed at improving services, and can be effectively experienced by professionals, managers and users of the health system ${ }^{(5)}$.

Based on the assumption that there must be an approximation between the transfer of TB control actions and PHC, on a political commitment of managers and the context of each scenario involved in order to carry out the DOT policy transfer process, the following question is posed: What are the effects of the meanings produced by the speeches of the managers on the transfer of the DOT strategy for TB control in priority municipalities for disease control in the region of Greater João Pessoa - Paraíba (PB)?

It is necessary to understand the meanings produced by the managers about the process of transfer of the DOT based on the conditions of each scenario described, as this analysis may favor the development of the different phases of DOT planning and lead to reflections on public policies for the control of tuberculosis.

The present study aimed to analyze the effects of meanings produced by the speeches of health managers on the Policy Transfer of the Directly Observed Treatment of Tuberculosis.

\section{METHOD}

Qualitative study developed in health services of three priority municipalities for TB control, namely Bayeux, Cabedelo and Santa Rita located in the Greater João Pessoa Region, in the state of Paraíba (PB). These municipalities have a geographically delimited area, with Family Health teams; Community Health Agents Program; Basic health Units; DOT implemented in the health system and involvement between the University/health services and the managers/ teams of the Disease Control Program and the Family Health Strategy/Epidemiological Surveillance.

The participants, here called speakers, were six managers in management positions in health services in the three municipalities investigated: a coordinator of the Tuberculosis Control Program, a coordinator of communicable diseases, a head of the Epidemiological Surveillance Division and three Health secretaries. Five participants have an academic background in the health area and one has a degree in Administration and Economics, with a Master's degree in the health area. 
The respondents were selected by convenience sampling, and the following inclusion criteria were adopted: having at least six months of experience in the position of health manager at the time of the interview. The subjects who were away from their activities during data collection, on vacation and/or sick leave were excluded.

The empirical material (speech corpus) was collected between the months of August and November 2017, in the workplaces of the participants. These were contacted by telephone to participate in individual interviews that were audio-recorded with the aid of a portable audio device.

The interviews, with an average duration of 30 minutes, were based on a previously tested guide suitable for the study setting. A field diary where notes were taken after the end of the interviews was used to record the conditions of corpus production and the duration of the interviews.

The speakers were motivated to talk about the Policy Transfer process, based on some of the following questions: 1. How do you describe your experience of implementation of the transfer of the DOT policy been with health professionals from Primary Care or Reference Units? 2. How has information related to DOT been discussed with the different levels of coordination and with primary care professionals or in the Reference Units? 3. What strategies have been used to involve/motivate DOT professionals at the municipal level? 4. What facilities and barriers have been encountered in the implementation of the DOT? 5. What adjustments have been necessary to ensure the transfer of the DOT policy? 6. What would you highlight as innovative regarding the implementation of the DOT?

To guarantee the anonymity of the speakers, the interviews were coded with letters HM (Health Manager), followed by the interview order numbers (HM1 to HM6).

French Discourse Analysis (DA) proposed by Michel Pêcheux was used as a theoretical-analytical framework of the speech corpus because it allows the identification of the subject-position of the speaker, is anchored on history, psychology and ideology and allows demonstrating the affiliation of the subjects and the production of meanings ${ }^{(7)}$.

The corpus was previously organized and aligned with the objective of the study, the production conditions and the ideological perception identified in the speeches, comprising the passageway from the empirical data to the discursive object through the following steps of analysis: 1. from the linguistic surface (text) to the discursive object (discourse); 2. from the discursive object to the discursive formation (DF); and 3. from the discursive process to ideological formation $(\mathrm{IF})^{(7)}$.

After a careful reading, in step 1, which concerns the passage from text to spoken discourse, the ideas, trends and opinions associated to the speeches of the managers were recognized in a social, historical and ideological context. Then, the managers, their respective speeches and the way they were delivered were identified, as well as which discursive circumstances contributed to the DFs ${ }^{(8)}$.

In step 2, which consists in the passage from discursive object to Discursive Formation, an attempt was made to identify the similarities of meanings constructed by the text. Linguistic marks were extracted and defined for the identification of the ideological aspects on which the discourse is based, and these aspects were grouped into eight DFs, as shown in Charts 1 and 2.

In step 3, which consists in the passage from the discursive process to Ideological Formation, focus was given to how ideology permeated textualization, as the DF generally guides the ideological context of the discourse, in the passage from empirical to discursive subject ${ }^{(8)}$. The research project was approved by the Research Ethics Committee of the Health Sciences Center of Universidade Federal da Paraíba, under protocol No. 0193/2017/CEP/CCS/UFPB, and ethical aspects were observed according to Resolution no 466/2012 of the National Health Council (CNS). All participants signed the Informed Consent Form (FICF).

\section{RESULTS AND DISCUSSION}

After analytical reading of the speeches, two discursive blocks were identified: (I) Favorable aspects to the Transfer of the DOT Policy on Tuberculosis and (II) Barriers to the operationalization of the Policy Transfer of the DOT of Tuberculosis.

\section{Aspects favorable to the Policy Transfer of the DOT of Tuberculosis}

In this first discursive block, the linguistic marks underlined in the discursive fragments enabled the construction of three discursive formations that translated the discourses of the managers regarding aspects favorable to the operationalization of PT, namely: investment in human, technological, physical and material resources; coordination of management in the organization of the network and awareness raising, as well as the participation of the health professionals involved.

In Chart 1, below, the linguistic marks that demonstrated the production of meanings based on what managers perceived as facilitating elements of the work process and of coordination with other levels of management were presented. These aspects drove the DOT transfer process in and to the municipalities. 
In the first discursive formation that deals with investment in human, technological, physical and material resources; the speakers considered the investment made as a facilitating element in the process of consolidating the policy transfer for TB control. In the spoken statement of HM1, a valuable resource was the double employment relationship of the participant, as he also assisted patients in the Reference Unit, at state level. The respondent had direct access to the tertiary reference unit for TB cases, which made it easier to identify patients from the municipality where the participant is a health manager who were assisted in the referred tertiary unit.

The different roles played by the subject, as a professional and manager, were perceived as a positive aspect, as they facilitated the coordination related to the TB control process in the different institutions. However, some aspects may not have contributed to TB control, as in the case where a single person is assigned responsibilities for the flows, a process previously institutionalized in the care network system,

\begin{tabular}{|c|c|}
\hline $\begin{array}{l}\text { Discursive } \\
\text { formations }\end{array}$ & Text segmentation \\
\hline \multirow{5}{*}{$\begin{array}{l}\text { Investment } \\
\text { in human, } \\
\text { technological, } \\
\text { physical and } \\
\text { material resources }\end{array}$} & $\begin{array}{l}\text { As I also work [...] (in the Reference Unit) [...], this has made my work easier [...] I've been making } \\
\text { improvements to the city that would have been difficult to achieve if I was not there [...] (HM1) }\end{array}$ \\
\hline & $\begin{array}{l}\text { [...] we had already talked to this lung specialist, we asked him to pay more attention to } \\
\text { tuberculosis, and as he has a postgraduate and master's degree in the area, everything was much } \\
\text { easier [...] (HM4) }\end{array}$ \\
\hline & $\begin{array}{l}{[. . .] \text { the material used by the Ministry of Health, that is the Clinical Management of Tuberculosis, }} \\
\text { which is very interactive, right? [...](HM4) }\end{array}$ \\
\hline & $\begin{array}{l}{[. . .] \text { bacilloscopy is performed here at our Lacen - a laboratory for these exams, and also X-ray [...] in }} \\
\text { the hospital [...] (HM3) }\end{array}$ \\
\hline & $\begin{array}{l}\text { If the diagnosis is made there (RU), the nurse sends the notification [...] via WhatsApp, [...] this has } \\
\text { improved substantially (HM2) }\end{array}$ \\
\hline \multirow{4}{*}{$\begin{array}{l}\text { Coordination of } \\
\text { management in } \\
\text { the organization of } \\
\text { the network }\end{array}$} & $\begin{array}{l}{[. . .] \text { through partnerships, }[. . .] \text { the state Lacen, to give us diagnostic support, }[. . .] \text { the Reference }} \\
\text { Laboratory, [...] which has also helped us in this fight, and [...] (in the Reference Unit), because we } \\
\text { are trying to decentralize the process }[. . .](\mathrm{HM} 1)\end{array}$ \\
\hline & $\begin{array}{l}{[. . .] \text { we open a CAPS, }[. .] \text { the coordinator of Primary Care, the supporter, }[. . .] \text { coordinator of the NASF, }} \\
{[. . .] \text { I have being talking a lot with them }[. . .](\mathrm{HM} 4)}\end{array}$ \\
\hline & $\begin{array}{l}{[. . .] \text { internal coordinations }[. . .] \text { and we also have close ties with the State Health Surveillance, }[. . .] \text { and }} \\
\text { there is also Social Action and Education. (HM6) }\end{array}$ \\
\hline & $\begin{array}{l}{[. . .] \text { partnerships with universities }[. . .] \text { the academics participate effectively, }[. . .] \text { and we still have full }} \\
\text { support from the mayor's office, [...] for all events, full support [...] (HM3) }\end{array}$ \\
\hline \multirow{2}{*}{$\begin{array}{l}\text { Awareness and } \\
\text { participation } \\
\text { of health } \\
\text { professionals involved }\end{array}$} & $\begin{array}{l}{[. . .] \text { the Surveillance team is concerned with Tuberculosis, which is very positive [...] it is no use }} \\
\text { having a structure, but not having the will to act, having professionals who are not sensitive to this } \\
\text { disease, not concerned with it, and who do not want to leave their comfort zone [...] (HM4) }\end{array}$ \\
\hline & {$[\ldots]$ the professionals, they are absorbing everything $[. .].(\mathrm{HM} 6)$} \\
\hline
\end{tabular}

Chart 1 - Aspects favorable aspects to the policy transfer of the DOT of Tuberculosis in priority municipalities in the Greater region of João Pessoa-PB, Brazil - 2017

Source: Research data, 2017. 
which should normally occur without the interference of a mediating element, which contrasts with the guidelines of the health system and the prerogatives of the Health Care Networks (HCNs).

Such aspects have improved the understanding of the effects of the meanings produced by an autocratic discourse, generated by production conditions restricted to the performance of different roles and that determined an ideological affiliation, or else, "I talk about what I live, I talk about what I $\mathrm{am}^{\prime \prime}(9)$.

In his/her statement, by affirming the importance of a specialist doctor in the area, HM4 produced a meaning effect of a facilitator of the process, regarding diagnostic elucidation, adherence to the therapy prescribed and monitoring of patients, a reality that is not always shown in the municipalities investigated.

The entry point to the TB care structure is Primary Care where the health care team is made up of health professionals and general practitioners. On the other hand, secondary care units have multidisciplinary teams with specialists in the area or who have experience in the subject, as these units are reference for cases that require more clarifications for a definitive diagnosis; drug intolerance management and "worse" adverse effects. As for tertiary units, professionals must have training and experience in the management of TB cases with high clinical complexity related to drug resistance ${ }^{(3)}$.

Health teams must participate in continuing education programs, as most actions targeted to the management of TB are not necessarily the responsibility of specialists, but of professionals with great technical-scientific knowledge, and so constant updating and, when possible, supervision, is required. Thus, a proposal centered on meaningful learning produces meanings that transform professional practices based on critical reflection, re-signifying them and qualifying all those involved to strengthen the DOT policy in the municipality ${ }^{10)}$

In a discursive fragment, speaker HM4 acknowledged that the Ministry of Health has been concerned with the transfer of information through established protocols for the control of TB. With its updates, this manual is considered a guiding tool aimed to the qualification and organization of health services and preventive and surveillance actions, elucidation of diagnoses and prescription of treatment regimen in TB cases, especially in $\mathrm{PHC}{ }^{(3)}$.

The statement of speaker HM3 produced meanings about the importance of technological resources, such as, for example, the offer of bacilloscopy exams and images available in the municipal network. In fact, this type of investment has been emphasized by the Ministry of Health when it reiterates the importance of structuring the health care network at the municipal level and the laboratory support network as main allies in the identification of symptomatic respiratory patients, in the diagnostic elucidation and in the early initiation of treatment ${ }^{(3)}$.

On the other hand, in the HM2 fragment, WhatsApp ${ }^{\oplus}$ Messenger was used as a valuable technological tool for health professionals, which has facilitated the daily work of the management with the health teams and of these teams and the community. This application enables fast communication via text, voice, image, music and video messages over the Internet. Despite its growing use in the health area and the satisfactory results obtained ${ }^{(11)}$, further studies on the regulations on safety care and ethical responsibilities in the sharing of patient information via WhatsApp are needed (11-12).

Another meaning issued by the speeches of the speakers concerned the discursive formation that addressed the coordination of management in the organization of the network. These actors reported promising references in the municipality, as well as in its relations with the State and universities. The importance of cooperation between decision-makers and reference laboratories in the state of Paraíba, to facilitate the decentralization of TB management policies and actions, was demonstrated. The speeches also revealed a meaning of challenge regarding the strengthening of TB policy.

In the meanings of the speech made by respondent HM6s, the relationships between the local health services were marked by the use of a metaphor in the textual mark - "we have a very close bond" - which discursively defined the excellent relationship with other managerial levels of management itself. The metaphor, in turn, constitutes the production of meanings by the respondent and the very constitution of the subject. It is a common feature present in communication, and is often caused by the sliding of meanings, when there is a transfer of meaning from one word to another, which can cause different events, through the interpretation, ideology and historicity that surround the speaker ${ }^{(7)}$.

The meanings produced by the speech of speaker HM3 showed evidence of another typology, the political speech, which can be explained by the fact that the respondents were managers, ideologically subjecting themselves to the municipal manager. This subjection provides essential conditions for the speaker to become the subject of his/her speech by freely submitting to the production conditions imposed by the established higher order, despite his/her illusion of autonomy ${ }^{(13)}$.

As for the discursive formation on awareness and participation of the health professionals involved in the policy transfer process, the compassionate speech of $\mathrm{HM} 4$ exposed 
the idea that sensitivity towards TB patients is a facilitating aspect of this process. The respondent stated that everyone (health managers or professionals involved in the patient care process) should be "willing"to seek something, "sensitive" and "face" the disease by stepping outside of their "comfort zone".

It can be said that being sensitive and committed is not related to the speaker's position, but is circumscribed to the interest in the common good, in the special and individualized "attention" and to what the disease symbolically represents for him/her, the population and, in particular, for the TB patient - the Other.

A study on communication and the ethics of Alterity, based on Levinas's idea, invites the subject to reflect beyond ethical responsibilities towards the Other, whose existence, demands and suffering will not only imply the need to help and respond to their call, but also to understand that the other affirms and makes human the very existence of the subject ${ }^{(14)}$.

When HM6 pointed that "they have been absorbing everything", which, for him/her, is considered a favorable aspect, the speech refers to the image of a vertical management, in which health team professionals have become mere information recipients. Discourse analysis showed, in a paraphrase, that if they (managers) "are absorbing", it is because someone is passing on information and regarding the policy transfer aspect, the speech, in addition to revealing a meaning of transfer of data, expressed a broader meaning in processes of transforming data into knowledge.

In discussions on the aspects favorable to the policy transfer of DOT of tuberculosis, most managers identified some resources already used in their respective municipalities as facilitators of the TB control process, without specifically emphasizing favorable aspects of the DOT transfer process.

\section{Barriers to the operationalization of Policy Transfer of DOT of Tuberculosis}

In this discursive block, five discursive formations were constructed, as shown in Chart 2. The meanings revealed the barriers to strengthen the process of policy transfer and TB control, such as cases diagnosed and treated in the Reference Unit; turnover of professionals; prejudice and social vulnerability; difficulty adhering to treatment and poor knowledge of health professionals. From the point of view of the discourse, it was found that the HM did not express their views on the operationalization of the DOT transfer process itself.

The cases diagnosed and treated at the Reference Unit, in the capital of the state of Paraíba, were perceived as an obstacle to the efforts to strengthen the TB control policy, since most patients traditionally resort to this hospital unit as their first option for the diagnostic elucidation and prescription of TB therapy. In the speech made by HM1, the meanings revealed that the manager, upon taking office, encountered a critical scenario that limited the expansion of the TB control policy, due to the lack of monitoring of patients, high rates of non-completed treatments and an inefficient information system.

The speeches of managers HM2 and HM4 were characterized as contradictory, as they attributed, the fact that TB patients do not seek local health services at the same time to a "vice", which is controlled by the subject's own discursive memory - the effect of a centralized model, and because they believe that TB patients do not seek the hospital units of their municipalities because these cannot provide adequate care, and consequently they seek the State Reference unit.

A study on healthcare system bottlenecks that impact the PHC model identified limitations of the service network in terms of diagnostic elucidation and monitoring of TB sufferers in PHC. These limitations include attitudes suggestive of discrimination on the part of health team professionals; limits regarding access to exams and routine appointments and difficulties in the referral system and counter-referral of TB patients ${ }^{(9)}$

Such aspects can create in the collective imagination the idea of the low effectiveness of local health systems, which, in part, collaborated with the HM4's discursive memory about disbelief in PHC. However, the speech of HM4 did not mention the strong presence of the Reference Unit, over the years, in the regional organization of health services for TB care, which is still perceived by the population and health professionals as the main TB treatment site.

The organization and effectiveness of PHC in different Brazilian municipalities reflect the way in which the hegemonic model of health care continues to be perpetuated, which culminates in discontinued, non-dialogical and timeless care practices, mischaracterizing the formation of strong health networks idealized by the health system ${ }^{(15)}$

Regarding the discursive formation related to the turnover of professionals, a study on TB conducted in Paraíba emphasized that this turnover is one of the main problems in the planning of care actions and patient follow-up in $\mathrm{PHC}^{(6)}$.

High staff turnover rates have been noticed in health care teams and in municipal managers responsible for the Tuberculosis Control Program. This has contributed to the discontinuity of ongoing work processes ${ }^{(9)}$ and has negatively affected the TP process, because constant changes in health care teams result in the loss of information and knowledge, which is even more complex when it comes to the care provided to socially vulnerable populations, such as TB patients. 


\begin{tabular}{|c|c|}
\hline Discursive formations & Text segmentation \\
\hline \multirow{3}{*}{$\begin{array}{l}\text { Cases diagnosed } \\
\text { and treated in the } \\
\text { Reference Unit }\end{array}$} & $\begin{array}{l}{[. . .] \text { these patients had not been seen for more than } 2 \text { years; so the patients were all seen in the }} \\
\text { reference unit [...] when we assessed the situation: the cure down there, neglect up there, you } \\
\text { see, [...] no information [...] (HM1) }\end{array}$ \\
\hline & $\begin{array}{l}{[. . .] \text { It became a habit... in pain, has a fever, and coughing? Goes to [...] (Reference Unit) [...], the }} \\
\text { patient often is not even referred to the hospital in his own municipality, because he thinks it is } \\
\text { no use, [...] due to the lack of proper health care assistance in the municipality... (HM4) }\end{array}$ \\
\hline & $\begin{array}{l}\text { [...](in the Reference Unit)[...] can schedule an X-ray, a bacilloscopy and an appointment with } \\
\text { a lung specialist only on day X, [...] rapid test that detects the bacillus within two hours and } \\
\text { indicates whether it is resistant to multiple drugs [...] (HM2) }\end{array}$ \\
\hline \multirow{2}{*}{ Professional turnover } & $\begin{array}{l}{[. . .] \text { the municipality is also facing some difficulties, from a political point of view, }[. . .] \text { changes }} \\
\text { are always going on there, right? [...] this is happening there more often this year, [...] (HM4) }\end{array}$ \\
\hline & [...]professional turnover is a complicating factor [...] (HM2) \\
\hline \multirow{4}{*}{$\begin{array}{l}\text { Prejudice and } \\
\text { social vulnerability }\end{array}$} & $\begin{array}{l}{[. . .] \text { it (TB) is a disease that generally leads to segregation of sufferers because of the risk of }} \\
\text { contamination, and TB sufferers are discriminated against by people who are afraid of getting } \\
\text { infected by the disease [...] (HM5) }\end{array}$ \\
\hline & $\begin{array}{l}\text { [...] there are many alcohol and drug users here, which is a big problem, a big challenge } \\
{[. . .](\mathrm{HM} 1)}\end{array}$ \\
\hline & $\begin{array}{l}{[\ldots . .] \text { because of the port issue, because of TB/AIDS co-infection, we [...] started to consider [...] }} \\
\text { this municipality as a priority [...] (HMS4) }\end{array}$ \\
\hline & [...] we have a port area, can be considered a barrier, a difficulty [...] (HMS3) \\
\hline $\begin{array}{l}\text { Difficulty adhering } \\
\text { to treatment }\end{array}$ & $\begin{array}{l}\text { [...] the health agents cannot monitor TB patients who work all day and take the medication } \\
\text { very early in the morning, right? there are drug users, there is a lot of prostitution, anyway, } \\
{[. . .] \text { it's difficult enough for a health agent to come to your house, to see that you take the }} \\
\text { medicine, let alone for TB patients to report every day to a health unit that 'should [...] be close } \\
\text { to their homes, but usually is not (HM2) }\end{array}$ \\
\hline \multirow{2}{*}{$\begin{array}{l}\text { Lack of knowledge of } \\
\text { health professionals }\end{array}$} & $\begin{array}{l}{[. . .] \text { I think people do not understand the DOT as an effective part of drug treatment [...] the }} \\
\text { professionals who administer it and who carry out this monitoring do not understand the } \\
\text { policy [...] This is too complicated. [...] (HM2) }\end{array}$ \\
\hline & $\begin{array}{l}{[. . .] \text { They do not go, do not attend the mobilization and updating programs, and they (health }} \\
\text { agents) are the ones who receive patients with Tuberculosis, [...]They think they are experts on } \\
\text { the subject, I've often heard them say, "ah, I've treated a lot of people with Tuberculosis, I know } \\
\text { how it is," [...] they think they don't need to participate in the programs[...] (HM2) }\end{array}$ \\
\hline
\end{tabular}

Chart 2 - Barriers to the operationalization of policy transfer of DOT of tuberculosis in priority municipalities in Greater João Pessoa-PB, Brazil - 2017

Source: Research data, 2017. 
Therefore, such turnover has increased the precariousness of labor relations, as it is inversely contrary to the fundamental principles of the health system, such as equity and longitudinality, for example, which could be ensured through public contests and the establishment of guidelines for the institution of a career, posts and wages policy.

As for discrimination, identified as a barrier to TB control, HM5 reported that this disease "generates this type of segregation of people" and reveals a natural meaning perceived by both health professionals and patients' families and the population in general.

Naturalization of stigmatizing and discriminating attitudes towards TB patients generated strong negative reactions in these patients, which have substantially contributed to social isolation, low self-esteem and difficulties in adhering to therapy, culminating in treatment abandonment ${ }^{(9)}$. These discriminatory aspects must be (self) monitored by health teams in order to improve one of the fundamentals of policy transfer - to maintain and expand TB control policies within the scope of PHC.

In this discursive formation, with regard to social vulnerability, $\mathrm{HM} 1$ and $\mathrm{HM} 4$ also reported other social determinants as barriers to successful TB control and involved social and economic indicators,comorbidities related to HIV/AIDS, in addition to the adoption of a lifestyle that favors illness and mortality, such as alcoholism and chemical dependence.

These and other factors have shown how complex the management of DOT policy transfer is and reiterate the need for new organizational models to manage $\mathrm{TB}^{(5)}$, with qualified teams for the welcoming approach and strategies aimed at the singularities of care ${ }^{(3)}$ Thus, the innovations expected in this process, within the scope of PHC, may be inspired by other experiences and positively influence other health policies.

It was found that only HM4 mentioned AIDS as a social determinant. His/her discursive memory was challenged by ideology as he/she turned to past times when he/she exercised his/her professional activities, delivering a health discourse that identified the port municipality as a priority for TB/HIV comorbidity. Surprisingly, the two managers from the port municipality did not mention the port area as a priority for the sanitary control of TV/HIV in their speeches. Their silence confirmed a worrying reality, given the spread of HIV infection worldwide ${ }^{(16)}$.

This situation is even more concerning because TB is an opportunistic disease that has been responsible for the highest rates of death from infectious disease in people infected with HIV/AIDS, despite the reduction in mortality from HIV/ AIDS with the use of antiretroviral therapy ${ }^{(4)}$. The Ministry of Health emphasizes that early diagnosis of HIV infection in
TB patients has an important impact on the clinical course of both diseases and recommends strengthening the TB monitoring system, through the coordination of different strategic areas, such as health surveillance, AIDS monitoring and $\mathrm{PHC}(2-3)$.

As for the fragments of the discursive formation that addressed the difficulties in adhering to the treatment, $\mathrm{HM} 2$ problematized aspects with negative effects on TB control, such as the difficulties in accessing the health unit in relation to the unavailability of suitable times for appointments for TB patients, as well as to the distance between the health unit and the patients' residences.

The discursive emphasis brought together various elements of the context and lifestyle of patients, considered as barriers to the operationalization of the DOT, but did not mention negotiations for possible changes. These linguistic marks are recurrent in the speeches of health professionals, managers and other members of civil society who distance themselves from the recommendations of the DOT protocol, which emphasizes the reduction of the physical distance between the health unit and the patient, considering time, transport and the financial expenses to receive supervised treatment ${ }^{(5)}$, aspects widely discussed in the policy transfer model based on innovation, but neglected by public policies.

Regarding adherence to drug therapy, the Pan American Health Organization (PAHO) strongly recommends that care be anchored on the principle of comprehensiveness, through a qualified multidisciplinary team that invests in co-responsibility strategies for TB patients, involving care, bond, trust and careful listening, aiming to strengthen the process of treatment adherence ${ }^{(17)}$.

As for the DOT, in addition to building the bond, it is recommended that health professionals or other trained professionals observe the daily intake of medication under the supervision of a health professional. This is necessary for notification purposes. On days when there is no observation of the treatment, such as during weekends and holidays, it is recommended that successive explanations be given to patients to ensure that the medications are self-administered daily ${ }^{(3)}$.

As for the discursive formation regarding the poor knowledge about TB by health professionals, the speech of HM2 expressed the transfer of responsibility to the team members, affirming that, in addition to not understanding this policy, the team members do not participate in TB training programs offered by the management, as they believe they know very well the aspects surrounding the control of the disease. However, HM2 does not mention the possible causes of these professionals' lack of motivation or the continuing education model present in that scenario. 
The use of the DOT as a tool in TB control actions brings the health team closer to the social context of service users, minimizes the stigmatizing effects of the disease, facilitates the identification of vulnerabilities and creates a link between the team, individuals and their families. This humanized approach by health professionals, in addition to contributing to the adoption of measures that prevent treatment abandonment, also taking into account the means that facilitate patients'displacement, empowers the subject to participate directly in the construction of care, through a dialogic and unique education (3).

Thus, in the policy transfer model, it is important to give more attention to care, be committed and responsible towards the other, invest in effective strategies that seek to elevate the "Other" to the condition of a subject, seek connections and flows to obtain inspiration for innovative experiences, or else make sure that local innovations serve as an inspiration for a new effective circuit of public TB care policies.

\section{口 FINAL CONSIDERATIONS}

The Policy Transfer related to the DOT of TB was not emphasized in the speeches, which points to an evident weakness in the implementation of this treatment and suggests that this strategy would be discussed later with PHC professionals, since most municipalities face critical scenarios that have jeopardized the patient care process and, therefore, the effectiveness of the DOT.

Discourse analysis showed that the effects of the meanings expressed by the speakers were also influenced by the conditions of production i.e., conditions restricted to the individuals and related to the macro environment through which they circulate. These effects of the meanings are marked by the individuality that drives their historicity, as social subjects, associated to their memories and ideologies. These meanings were also reflected by what was not said by the respondents, the contradictory, the paraphrases, the metaphors, the subjections, the omissions and the dimensions of Policy Transfer beyond the DOT, highlighting the variability of transfers based on the uniqueness of each space.

The study has important implications regarding the improvement of the management of clinical practice in $\mathrm{PHC}$, as it provides health managers with reflections on the need to prioritize policies to fight TB and encourage the implementation of the DOT- it is a strategy (tool) that can control TB, as long as it is coordinated in a network, with social assistance, with care centered on the individual, and not separately.
Furthermore, the study provides reflections on the lack of investments in all types of resources; the strengthening of the bond in PHC, referral and counter-referral; the evaluation and monitoring of TB indicators; the reorganization of the network from the perspective of care networks and the proposal of permanent education, considering the local specificities, in addition to reflecting on responsibility and patient-centered care that goes beyond the traditional disease-focused approach.

The small sample size (low number of participants) is a limitation of the present study, as well as the non-inclusion of other municipalities and states. Therefore, further studies are needed to expand knowledge about the transfer of DOT policies.

\section{REFERENCES}

1. World Health Organization (WHO). Global tuberculosis report 2020 [Internet]. Geneva:WH0; 2020. [cited 2020 Apr 02]. Available from: https://apps.who.int/ iris/bitstream/handle/10665/336069/9789240013131-eng.pdf

2. Ministério da Saúde (BR). Secretaria de Vigilância em Saúde. Vigilância em saúde no Brasil 2003|2019: da criação da Secretaria de Vigilância em Saúde aos dias atuais. Boletim epidemiológico [Internet]. 2019 [cited 2020 Apr 02];50(esp.):1154. Available from: https://portalarquivos2.saude.gov.br/images/pdf/2019/ setembro/25/boletim-especial-21ago19-web.pdf

3. Ministério da Saúde (BR). Secretaria de Vigilância em Saúde. Departamento de Vigilância das Doenças Transmissíveis. Manual de recomendações para 0 controle da tuberculose no Brasil. Brasília (DF): Ministério da Saúde; 2019 [cited 31 Jan 2021]. Available from: https://bvsms.saude.gov.br/bvs/publicacoes/ manual_recomendacoes_controle_tuberculose_brasil_2_ed.pdf

4. Shuhama BV, Silva LMC, Andrade RLP, Palha PF, Hino P, Souza KMJ. Evaluation of the directly observed therapy for treating tuberculosis according to the dimensions of policy transfer. Rev Esc Enferm USP. 2017;51e03275. doi: http://doi.org/10.1590/ S1980-220X2016050703275

5. Oliveira RCC, Adário KDO, Sá LD, Videres ARN, Souza SAF, Pinheiro PGOD. Managers' discourse about information and knowledge related to directly observed treatment of tuberculosis. Texto Contexto Enferm. 2016;25(2):e3210015. doi: https://doi. org/10.1590/0104-07072016003210015

6. Oliveira RCC, Sá LD, Dias DCB, Pinheiro PGOD, Palha PF, Nogueira JA. Speeches of managers aboutthe policy of the directly observed treatmentfor tuberculosis. Rev Bras Enferm. 2015;68(6):761-8. doi: http://doi.org/10.1590/0034-7167.2015680611i

7. Orlandi EP. Análise do discurso: princípios e procedimentos. 10. ed. Campinas: Pontes; 2012.

8. Souza SAF. Análise de discurso: procedimentos metodológicos. 2. ed. Manaus: EDUA; 2021.

9. Pinheiro PGOD, Sá LD, Palha PF, Oliveira RCC, Nogueira JA, Villa TCS. Critical points for the control of tuberculosis on primary health care. Rev Bras Enferm. 2017;70(6):1227-34. doi: http://doi.org/10.1590/0034-7167-2016-0467

10. Silva CM. Educação permanente na atenção à tuberculose: desencadeando processos de mudanças [Projeto de intervenção]. Natal: Universidade Federal do Rio Grande do Norte; 2017. [cited 02 Apr 2020]. Available from: https:// monografias.ufrn.br/jspui/bitstream/123456789/6533/1/PI\%20Cristiane\%20 Moraes\%20da\%20Silva\%20final\%20\%281\%29.pdf 
11. Lima ICV, Galvão MTG, Pedrosa SC, Cunha GH, Costa AKB. Use of the WhatsApp application in health follow-up of peoplewith HIV: athematic analysis. Esc Anna Nery. 2018;22(3):e20170429. doi: https://doi.org/10.1590/2177-9465-ean-2017-0429

12. Leão CF, Coelho MES, Siqueira A0, Rosa BAA, Neder PRB. The use of WhatsApp in the physician-patient relationship. Rev Bioét. 2018;26(3):412-9. doi: https:// doi.org/10.1590/1983-80422018263261

13. Ferreira MCL. Glossário de termos do discurso. Porto Alegre: UFRGS; 2001.

14. Martino LMS, Marques ACS. Communication as alterity's ethics: explorations with Lévinas. Intercom, Rev Bras Ciênc Comum. 2019;42(3):21-39. doi: https://doi. org/10.1590/1809-5844201931

15. Peruhype RC, Mitano F, Hoffmann JF, Surniche CA, Palha PF. Planning pathways in the transfer of directly observed treatment of tuberculosis. Rev Latino-Am Enfermagem. 2018;26:e3015. doi: https://doi.org/10.1590/1518-8345.2213.3015
16. Nogueira JA, Rodrigues JA, Silva RP, Ferreira GM, Alencar JMN, Rodrigues NR, et al. Vulnerabilidade feminina ao vírus da imunodeficiência humana - HIV: perfil sociodemográfico e comportamental sexual de jovens. Adolesc Saúde. 2017 [cited 02 Apr 2020];14(1):45-54. Available from: https://cdn.publisher.gn1.link/ adolescenciaesaude.com/pdf/v14n1a07.pdf

17. Organização Pan-americana da Saúde. Direitos humanos, cidadania e tuberculose na perspectiva da legislação brasileira [Internet]. Brasília (DF): OPAS; 2015. [cited 02 Apr 2020]. Available from: https://iris. paho.org/bitstream/handle/10665.2/7679/9788579670909_por. pdf;isessionid=FA6FEB3F90182EFFB40B109E626B7E7D? sequence $=1$ 
- Acknowledgments:

We thank the National Council for Scientific and

Technological Development (CNPq).

\section{- Authorship contribution:}

Conceptualization, Data curation, Formal analysis: Karinne Dantas de Oliveira Adário, Anne Jaquelyne Roque Barrêto, Rita de Cassia Cordeiro de Oliveira. Acquisition of funding: Pedro Fredemir Palha Investigation, Methodology, Project administration: Karinne Dantas de Oliveira Adário; Anne Jaquelyne Roque Barrêto

Visualization, Writing - original draft - review and editing: Karinne Dantas de Oliveira Adário; Anne Jaquelyne Roque Barrêto; Rita de Cassia Cordeiro de Oliveira; Arieli Rodrigues Nóbrega Videres; Amanda Haissa Barros Henriques; Pedro Fredemir Palha

The authors declare that there is no conflict of interests.

\section{- Corresponding author:}

Karinne Dantas de Oliveira Adário

E-mail: karinnedantasenf@gmail.com

\section{Associate editor:}

Carlise Rigon Dalla Nora 